Louisiana State University

LSU Digital Commons

Faculty Publications

Department of Biological Sciences

7-15-2016

\title{
PH-Dependent DNA Distortion and Repression of Gene Expression by Pectobacterium atrosepticum PecS
}

Dinesh K. Deochand

Louisiana State University

Jacob K. Meariman

Louisiana State University

Anne Grove

Louisiana State University

Follow this and additional works at: https://digitalcommons.Isu.edu/biosci_pubs

\section{Recommended Citation}

Deochand, D., Meariman, J., \& Grove, A. (2016). PH-Dependent DNA Distortion and Repression of Gene Expression by Pectobacterium atrosepticum PecS. ACS Chemical Biology, 11 (7), 2049-2056.

https://doi.org/10.1021/acschembio.6b00168

This Article is brought to you for free and open access by the Department of Biological Sciences at LSU Digital Commons. It has been accepted for inclusion in Faculty Publications by an authorized administrator of LSU Digital Commons. For more information, please contact ir@lsu.edu. 


\title{
pH-Dependent DNA Distortion and Repression of Gene Expression by Pectobacterium atrosepticum PecS
}

\author{
Dinesh K. Deochand, Jacob K. Meariman, and Anne Grove* \\ Department of Biological Sciences, Louisiana State University, Baton Rouge, Louisiana 70803, United States \\ Supporting Information
}

ABSTRACT: Transcriptional activity is exquisitely sensitive to changes in promoter DNA topology. Transcription factors may therefore control gene activity by modulating the relative positioning of -10 and -35 promoter elements. The plant pathogen Pectobacterium atrosepticum, which causes soft rot in potatoes, must alter gene expression patterns to ensure growth in planta. In the related soft-rot enterobacterium Dickeya dadantii, PecS functions as a master regulator of virulence gene expression. Here, we report that $P$. atrosepticum PecS controls gene activity by altering promoter DNA topology in response to $\mathrm{pH}$. While PecS binds the pecS promoter with high affinity regardless of $\mathrm{pH}$, it induces significant $\mathrm{DNA}$ distortion only at neutral $\mathrm{pH}$, the $\mathrm{pH}$ at which the pecS promoter is repressed in vivo. At $\mathrm{pH} \sim 8$, DNA distortions are attenuated, and PecS no longer represses the pecS promoter. A specific histidine (H142) located in a crevice between the dimerization- and DNA-binding regions is required for $\mathrm{pH}$-dependent changes in DNA distortion and repression of gene activity, and mutation of this histidine renders the mutant protein incapable of repressing the pecS promoter. We propose that protonated PecS induces a DNA conformation at neutral $\mathrm{pH}$ in which -10 and -35 promoter elements are suboptimally positioned for RNA polymerase binding; on deprotonation of PecS, binding is no longer associated with significant changes in DNA conformation, allowing gene expression. We suggest that this mode of gene regulation leads to differential expression of the PecS regulon in response to alkalinization of the plant apoplast.
$\mathrm{F}$ or transcription to occur, bacterial RNA polymerase holoenzyme must bind cognate promoter elements at -10 and -35 . Suboptimal spacings between these promoter elements, for example by increasing the spacer from the consensus $17 \mathrm{bp}$ to $19 \mathrm{bp}$, results in decreased polymerase binding and reduced transcription. ${ }^{1}$ Transcriptional regulators may therefore function by modifying promoter DNA conformation such that the relative placement of -10 and -35 promoter elements is altered.

Bacterial transcription factors often respond to environmental signals to effect changes in gene activity. For example, bacterial pathogens must adapt to the hostile environment created by host defenses to achieve successful infection, and the proper temporal expression of virulence genes is key. MarR (Multiple Antibiotic Resistance Regulator) family transcriptional regulators feature prominently in this context as they regulate cellular processes, including virulence, in response to environmental cues. ${ }^{2-4}$ Many MarR proteins are encoded divergently from a gene under their control and either repress or activate transcription of the genes in their regulons, a regulatory function that is modulated in the presence of a specific signal or ligand. ${ }^{4,5}$

The enterobacterium Pectobacterium atrosepticum (formerly Erwinia carotovora subsp. atroseptica) is among the most important phytopathogens, responsible for causing soft rot and blackleg disease in potatoes. ${ }^{6}$ Soft rot is characterized by maceration of plant cell walls due to secretion of degradative enzymes such as pectate lyases, cellulases, and proteases. Most soft rot Enterobacteriaceae belong to the genera Pectobacterium and Dickeya. The signals to which these bacteria respond in order to effect virulence gene expression range from $\mathrm{N}$-acylhomoserine lactone (AHL)-dependent quorum sensing to plant-derived factors. ${ }^{7,8}$ Taking advantage of natural openings or wounds, the bacteria colonize the plant apoplast, where they encounter the plant's defenses, such as oxidative stress, nutrient limitation, and bactericidal compounds. The mildly acidic $(\mathrm{pH}$ 5-6.5) environment of the apoplast is unfavorable for the function of pectate lyases, which have a $\mathrm{pH}$ optimum near 8.9 Soft-rot Enterobacteriaceae therefore produce acetoin, which functions to raise the $\mathrm{pH}$ of the apoplast. ${ }^{10}$ The production of reactive oxygen species (ROS) is another major plant defense strategy; thus neutralization of ROS by antioxidants is crucial for virulence of phytopathogens. ${ }^{10,11}$

Previous studies have shown that Dickeya dadantii PecS, a MarR family transcriptional regulator, is one of the primary regulators of virulence gene expression, for example negatively controlling the expression of pectinase genes and production and secretion of the antioxidant indigoidine. ${ }^{12,13}$ While $D$. dadantii PecS specifically binds to the intergenic region between divergent pecS and pecM genes leading to repression of both, the signals that lead to derepression remain to be

Received: February 22, 2016

Accepted: May 23, 2016

Published: May 23, 2016 
identified. $^{13}$ PecS from the plant pathogen Agrobacterium tumefaciens (now designated A. fabrum) has also been shown to regulate expression of a divergent pecM gene; for A. fabrum $\mathrm{PecS}$, urate was shown to be a potent ligand that leads to derepression of gene transcription. ${ }^{14}$ Urate is produced as a byproduct during ROS generation by plant xanthine oxidase, ${ }^{15,16}$ rationalizing why plant pathogens may detect this compound as a signal for successful host colonization and a contributing trigger of virulence gene expression.

We report here a novel mode of gene regulation by $P$. atrosepticum PecS in which PecS-mediated modulation of promoter DNA topology is controlled by $\mathrm{pH}$. We propose that protonated $\mathrm{PecS}$ induces a DNA conformation at neutral $\mathrm{pH}$ in which -10 and -35 promoter elements are suboptimally positioned for RNA polymerase binding; on deprotonation of PecS, binding is no longer associated with significant changes in DNA conformation, allowing gene expression. The physiological relevance of this observation is differential expression of the PecS regulon in response to alkalinization of the plant apoplast.

\section{RESULTS}

Sequence and Structural Analysis. PecS belongs to the urate-responsive transcriptional regulator (UrtR) subfamily of MarR proteins. UrtR proteins are characterized by an $\mathrm{N}$ terminal extension absent from canonical MarR proteins such as Escherichia coli MarR as well as additional signature residues (W24, D68, R75, R101; Supporting Information Figure S1), which may contribute to ligand binding. ${ }^{14,17,18}$ To identify bacterial species that conserve this transcription factor, we queried the STRING database ${ }^{19}$ with the PecS and PecM protein sequences from $A$. fabrum. STRING predicted conservation of divergent $p e c S-p e c M$ gene pairs in a limited set of evolutionarily distant bacterial species (Supporting Information Figure S2). Divergent pecS-pecM genes were for instance found among the gamma-proteobacterial family Enterobacteriaceae, particularly among the genera Dickeya and Pectobacterium.

The sequence alignment of $P$. atrosepticum PecS with other MarR homologues confirms the UrtR signature (Supporting Information Figure $\mathrm{S} 1$ ). The pairwise alignment shows that $P$. atrosepticum PecS is similar to D. dadantii and A. fabrum PecS with $48 \%$ and $46 \%$ sequence identity, respectively. In $D$. dadantii, A. fabrum, and Streptomyces coelicolor, PecS negatively regulates expression of the pecM gene by binding to the pecSpecM intergenic region. ${ }^{14,20,21} \mathrm{PecM}$ is annotated as a permease of the drug/metabolite transporter (DMT) superfamily, which in $D$. dadantii is responsible for efflux of the antioxidant indigoidine; ${ }^{13,22}$ pairwise alignment shows $43 \%$ identity between $D$. dadantii and $P$. atrosepticum PecM. Examination of the $P$. atrosepticum pecS-pecM intergenic region reveals the presence of two pseudopalindromic sequences that resemble the consensus UrtR binding site (TATCTTGANNTNa/ gAGATA; ${ }^{17}$ Figure 1a).

The pecS gene from $P$. atrosepticum was cloned, overexpressed in Escherichia coli, and purified to apparent homogeneity; as expected, PecS exists as a dimer in solution as determined by size exclusion chromatography (Supporting Information Figure S3c,d). The secondary structure composition of PecS was predicted by far-UV circular dichroism spectroscopy, yielding a composition that is similar to that of Deinococcus radiodurans HucR (Supporting Information Figure $\mathrm{S} 3 \mathrm{~b}) .{ }^{23}$ A three-dimensional model of PecS was generated using a

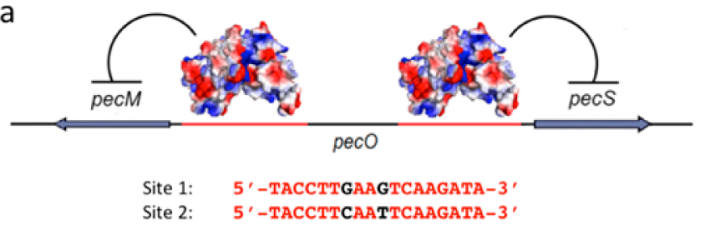

b

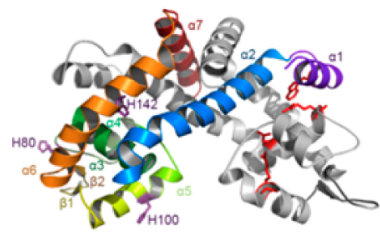

Figure 1. P. atrosepticum PecS. (a) Divergent pecM and pecS genes. The intergenic region contains two palindromes separated by $20 \mathrm{bp}$. One site is $1 \mathrm{bp}$ upstream of the start codon for PecS; the other site is $6 \mathrm{bp}$ upstream of the start codon for PecM. (b). Model of PecS. One subunit is shown in gray and the other in color. The conserved ligandcoordinating residues are shown as red sticks. The histidine residues are shown as magenta sticks.

the HucR structure as a template (Figure $1 b$ ). UrtR signature residues shown to coordinate urate in HucR occupy the predicted positions. Notable features of $P$. atrosepticupm PecS include the presence of a histidine in the DNA-recognition helix (H100) as well as a histidine facing the predicted ligandbinding pocket (H142)

pH-Dependent DNA Binding of PecS. DNA binding was measured using electrophoretic mobility shift assay (EMSA) using $92 \mathrm{bp}$ ( $p e c \mathrm{O})$ DNA containing the $p e c S-p e c M$ intergenic region. PecS bound this DNA with high affinity as evidenced by an apparent dissociation constant $\left(K_{\mathrm{d}}\right)$ of $1.0 \pm 0.1 \mathrm{nM}$ at $\mathrm{pH}$ 7.4 (Figure 2a and Supporting Information Figure S4). The Hill

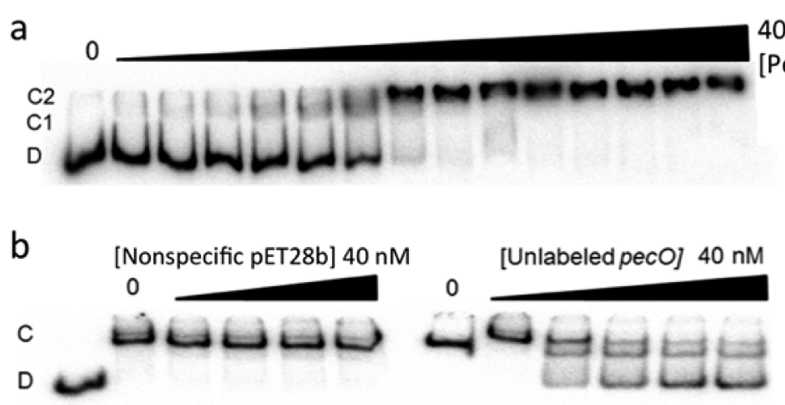

Figure 2. DNA binding and specificity of PecS. (a) EMSA showing binding of PecS to the pecS-pecM intergenic DNA at pH 7.4. [PecS] in lanes $2-15(\mathrm{nM}): 0.03,0.06,0.13,0.25,0.5,1.0,2.0,3.0,5.0,10,15$, 20,30, and 40. Complexes and free DNA are identified at the left. Experiments were performed in the equilibrium regime ([DNA] < $\left.K_{\mathrm{d}}\right)$. (b) Binding of $\mathrm{PecS}(2.5 \mathrm{nM})$ to $\mathrm{pecO}$ was challenged with increasing concentration $(2.5-40 \mathrm{nM})$ of nonspecific DNA (pET28b) or unlabeled pecO DNA.

coefficient $\left(n_{\mathrm{H}}\right)$ of $1.4 \pm 0.1$ suggests modest positive cooperativity. PecS formed two complexes with pecO, consistent with the predicted presence of two binding sites in the intergenic DNA (Figure 2a). To assess the specificity of DNA binding by PecS, we challenged the $\mathrm{PecS}-$ pecO complex with excess nonspecific DNA and unlabeled pecO. The titration of unlabeled pecO with $\mathrm{PecS}-\mathrm{pecO}$ complex showed competition for PecS binding. However, nonspecific DNA had no effect on DNA binding, which demonstrates that PecS binding to 
DNA is specific (Figure 2b). When EMSA was performed at $\mathrm{pH}$ 8.3, PecS-DNA complexes were unstable and dissociated during electrophoresis (Supporting Information Figure S5).

$\mathrm{PecS}$ contains several histidine residues. Considering the $\mathrm{p} K_{\mathrm{a}}$ of His, we speculated that His deprotonation might be responsible for the failure to detect a stable PecS-DNA complex at $\mathrm{pH}$ 8.3. In addition to three histidine-glutamate repeats at the $\mathrm{N}$-terminus, PecS has four histidines. The PecS model shows $\mathrm{H} 80$ at the surface in the loop between helix $\alpha 3$ and $\alpha 4, \mathrm{H} 100$ in the DNA recognition helix $(\alpha 5), \mathrm{H} 142$ in helix $\alpha 6$, facing the ligand-binding pocket, and H175 near the Cterminus (beyond helix $\alpha 7$; Figure $1 \mathrm{~b}$ and Supporting Information Figure S1). To verify $\mathrm{pH}$-dependent DNA binding by PecS, we performed a filter binding assay as a function of $\mathrm{pH}$ (Supporting Information Figure S6). PecS bound to DNA with modestly higher affinity at lower $\mathrm{pH}$, as evidenced by a gradual increase in the apparent dissociation constant $\left(K_{\mathrm{d}}\right)$ with increasing $\mathrm{pH}$; at $\mathrm{pH} 5.0$, the DNA binding affinity of PecS $\left(K_{\mathrm{d}}=1.2 \pm 0.1 \mathrm{nM}\right)$ was slightly higher in comparison to $\mathrm{pH}$ $8.0\left(K_{\mathrm{d}}=4.3 \pm 0.9 \mathrm{nM}\right)$. These data indicate that DNA binding by $\mathrm{PecS}$ is only modestly $\mathrm{pH}$-dependent, but favored at lower $\mathrm{pH}$.

To examine the protonation states of histidines, modification of PecS with diethylpyrocarbonate (DEPC) was carried out at $\mathrm{pH}$ 6.6, 7.0, 7.4, and 8.0. Unprotonated histidines react with DEPC and form carbethoxy-histidines. Upon the addition of DEPC, we observed an increase in histidine modification when $\mathrm{pH}$ was increased from 6.6 to 7.4 (Figure 3a), suggesting that the extent of histidine modification is $\mathrm{pH}$-dependent and that at
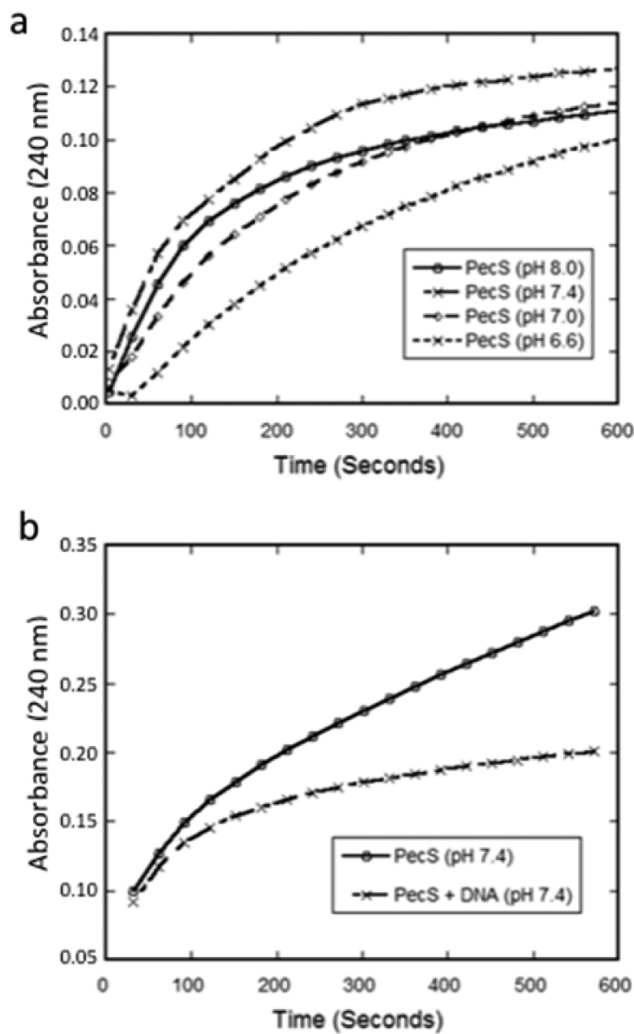

Figure 3. Modification of histidines by DEPC. (a) PecS and DEPC were mixed and the absorbance at $240 \mathrm{~nm}$ was recorded. (b) DEPC was added to PecS in the presence and absence of DNA containing a single binding site. The higher absorbance observed in comparison to panel (a) is due to presence of Tris, which reacts with DEPC. least one histidine has a $\mathrm{p} K_{\mathrm{a}}$ near 7 . The extent of modification of PecS by DEPC at $\mathrm{pH} 8.0$ was less than that at $\mathrm{pH} 7.4$, which might be due to reversibility of the carbethoxylated-histidine at alkaline $\mathrm{pH}^{24}$

PecS was modified with DEPC at $\mathrm{pH} 7.4$ in the presence of 40 bp DNA containing a single PecS binding site. The increase in absorbance at $240 \mathrm{~nm}$ was substantially less than for unbound protein (Figure $3 \mathrm{~b}$ ). This indicates that the presence of DNA prevents DEPC from modifying some histidines, either by shielding histidine directly or due to conformational changes that affect DEPC-accessibility of distant residues, and it implicates histidine in DNA binding by PecS.

PecS Distorts Its Cognate DNA Sites. To identify cognate sites in the pecS-pecM intergenic DNA, we performed DNase I footprinting by the fragment analysis method. ${ }^{25}$ A 317 bp fluorescently labeled DNA containing the pecS-pecM intergenic region was incubated with or without PecS before digesting it with DNase I. At a PecS concentration of $28 \mathrm{nM}$, two protected regions, $S 1$ and S2, spanning from -18 to +4 (23 bp) and -57 to $-34(24 \mathrm{bp})$, respectively, relative to the start codon of PecS were observed at $\mathrm{pH} 7.4$ (Figure 4b,d). At lower concentration of protein $(14 \mathrm{nM})$, protection at site S2 was incomplete, reflecting a modestly preferred binding to site $\mathrm{S} 1$ (Figure 4a). Both protected regions correspond to the identified palindromes, with protection starting at the upstream end of each palindrome and extending $6 \mathrm{bp}$ downstream. Notably, hypersensitive cleavage sites flanking each protected region (centered $7 \mathrm{bp}$ from either side of each palindrome) were observed at positions $-64,-33,-32,-26,-25$, and +6 . This is significant, because it suggests that PecS distorts the DNA upon binding.

A similar pattern of protection was observed at $\mathrm{pH} 8.3$ (Figure $4 \mathrm{c}$ and Supporting Information Figure S7a). However, while hypersensitive site positions are identical at $\mathrm{pH} 7.4$ and 8.3, hypersensitive cleavage is much less pronounced at $\mathrm{pH} 8.3$ even though protection of both palindromes is complete, suggesting full occupancy (Figure 5). This difference in hypersensitive cleavage suggests a DNA deformation upon PecS binding at $\mathrm{pH} 7.4$ that is virtually absent when $\mathrm{PecS}$ binds DNA at $\mathrm{pH} 8.3$.

To further investigate the effect of $\mathrm{pH}$ and the role of histidine on DNA binding by PecS, we created two mutants, PecS-H100F and PecS-H142F; $\mathrm{H} 100$ is in the DNA recognition helix and might be involved in direct contacts to DNA, and H142 faces the predicted ligand-binding pocket (Figure $1 b$; for further justification, see Supporting Information).

Consistent with $\mathrm{H} 100$ being predicted to be surface-exposed, thermal stability of PecS-H100F was not appreciably different from that of wild-type PecS (measured at $\mathrm{pH} 7.4$; data not shown). Footprinting performed with PecS-H100F (28 nM) at $\mathrm{pH} 7.4$ did not show any protection, only a hypersensitive cleavage at position -69 (Supporting Information Figure S7b). Using higher protein concentration $(56 \mathrm{nM})$, PecS-H100F protection resembled that of wild-type $\mathrm{PecS}$, including the flanking hypersensitive sites (Figure 6a). However, we observed three additional hypersensitive sites at $-69,+59$, and +106 . EMSA with PecS-H100F indicated an approximately 1.5 -fold decrease in affinity $\left(K_{\mathrm{d}}=2.5 \mathrm{nM}\right.$; Supporting Information Figure S8), suggesting that DNase I footprinting was performed under stoichiometric conditions as for wild-type PecS. Noting that expression of PecS-H100F in E. coli was much lower than that of wild-type PecS as judged by protein content in whole 
a

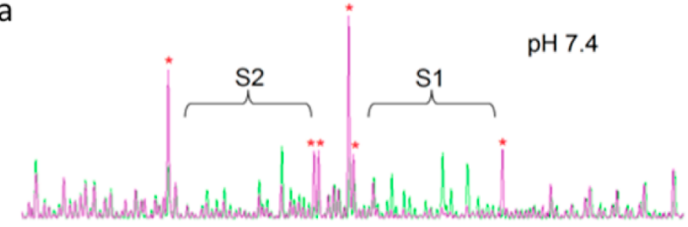

b

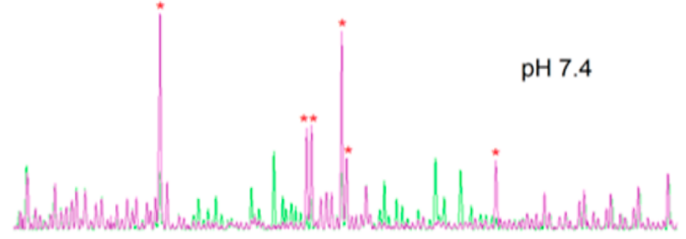

C

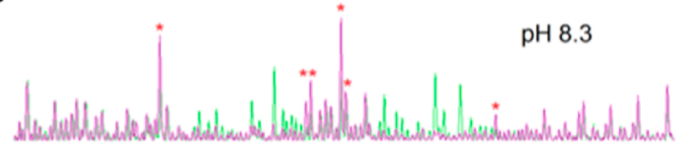

d

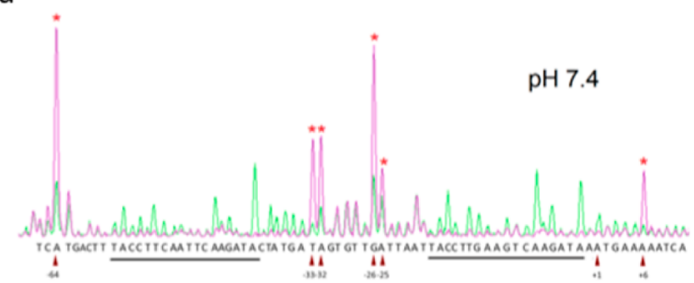

Figure 4. DNase I footprint of PecS binding to pecS-pecM intergenic DNA. (a) DNase I digestion of DNA performed at $\mathrm{pH} 7.4$ without (green) or with PecS (14 nM; magenta). Two protected regions, S1 and S2, are identified. (b) DNase I digestion at $\mathrm{pH} 7.4$ without (green) or with PecS (28 nM; magenta). (c). DNase I digestion at $\mathrm{pH} 8.3$ without (green) or with PecS (28 nM; magenta). The $y$ axis (in arbitrary units) is constant in panels $a-c$, as reflected in equivalent height of peaks at the far left and far right, where cleavage was unaffected by protein addition. (d) Expanded view of protected regions ( 1 1 and S2) from panel b. The DNA sequence is shown, and the palindromes are underlined. The sequence numbering is relative to the start codon of PecS, defined as +1 . ( $a-d)$ Hypersensitive sites induced by PecS binding to DNA are represented with red asterisks. Experiments were performed under stoichiometric conditions ([DNA] $\left.\gg K_{\mathrm{d}}\right)$.

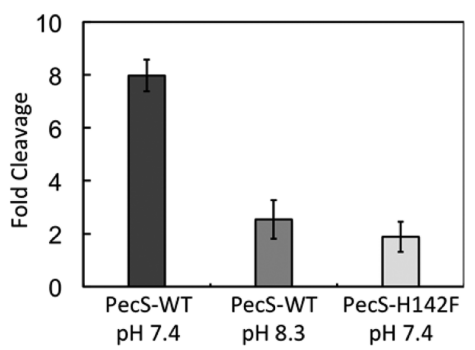

Figure 5. Quantitation of hypersensitive cleavage. The relative intensity of cleavage at sites identified by asterisks in Figure 4. Peak heights for all six marked hypersensitive sites were totaled and normalized to the sum of peak height for six peaks not altered by protein binding. Error bars represent standard deviation.

cell lysate (Supporting Information Figure S9), an outcome that would be expected if PecS-H100F bound DNA less specifically and interfered with normal cellular function, we therefore surmise that the additional hypersensitive sites reflect binding to alternate sites.
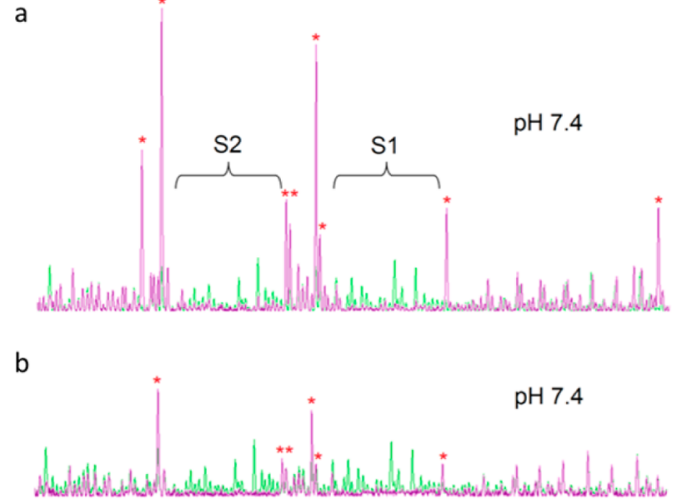

Figure 6. DNase I footprint of PecS variants. (a) DNase I digestion without (green) or with PecS-H100F (56 nM; magenta). The two protected regions are identified by brackets; note that the $x$-axis is expanded relative to that shown in Figure 4 to include additional hypersensitive sites. (b) DNase I digestion without (green) or with PecS-H142F (28 nM; magenta). (a,b) Red asterisks indicate the hypersensitive sites. Experiments were performed under stoichiometric conditions $\left([\mathrm{DNA}] \gg K_{\mathrm{d}}\right)$.

The footprint of PecS-H142F revealed an identical protection pattern to wild type $\mathrm{PecS}$, including preferred protection of site S1 (Supporting Information Figure S7c). Complete protection was observed at the same concentration (28 nM; Figure 6b) required for complete protection by wildtype PecS (Figure 4b). However, hypersensitive cleavage was much less pronounced compared to wild type PecS (Figures 5 and $6 \mathrm{~b})$. Taken together, our data indicate that PecS induces significant DNA distortion at neutral $\mathrm{pH}$, but not at mildly alkaline $\mathrm{pH}$. Notably, the $\mathrm{H} 142 \mathrm{~F}$ substitution yields a mutant protein that does not induce the marked DNA distortions characteristic of wild-type PecS. For wild-type PecS, this suggests that protonation of His 142 induces conformational changes that propagate to the DNA-binding motifs and that DNA-binding by protonated PecS requires DNA distortion. By contrast, the disposition of DNA recognition helices in deprotonated $\mathrm{PecS}(\mathrm{pH} \sim 8)$ or PecS-H142F is compatible with binding in consecutive DNA major grooves without the need for major DNA distortion. That the H142F substitution imposes changes in protein structure or dynamics is supported by the observation that PecS-H142F exhibits a modestly lower thermal stability at $\mathrm{pH} 7.4\left(45.5 \pm 0.6{ }^{\circ} \mathrm{C}\right.$ compared to $51.2 \pm$ $1.2{ }^{\circ} \mathrm{C}$ for wild-type PecS), consistent with $\mathrm{H} 142$ occupying a more buried position near the ligand-binding pocket.

pH-Dependent Control of Gene Expression. A transcriptional reporter construct was created in which the gene encoding enhanced green fluorescent protein (EGFP) is under control of the pecS promoter ( $p e c O)$. In E. coli carrying pACYC184 EGFP pecO and pET100-PecS in which PecS expression was not induced by IPTG, the cells expressed EGFP at $\mathrm{pH} 7$ (Figure 7a, right panel). However, when PecS expression was induced, no fluorescence was observed, indicating that expression was repressed by PecS (Figure 7b, left panel). Since PecS was expected to respond to urate with attenuated DNA binding as observed for other PecS proteins, ${ }^{14,20}$ urate was added to cultures in which PecS expression had been induced. The addition of urate to PecS expressing cells was found to markedly induce the expression of EGFP (Figure $7 \mathrm{~b}$, right panel). This suggests that urate acts as a 


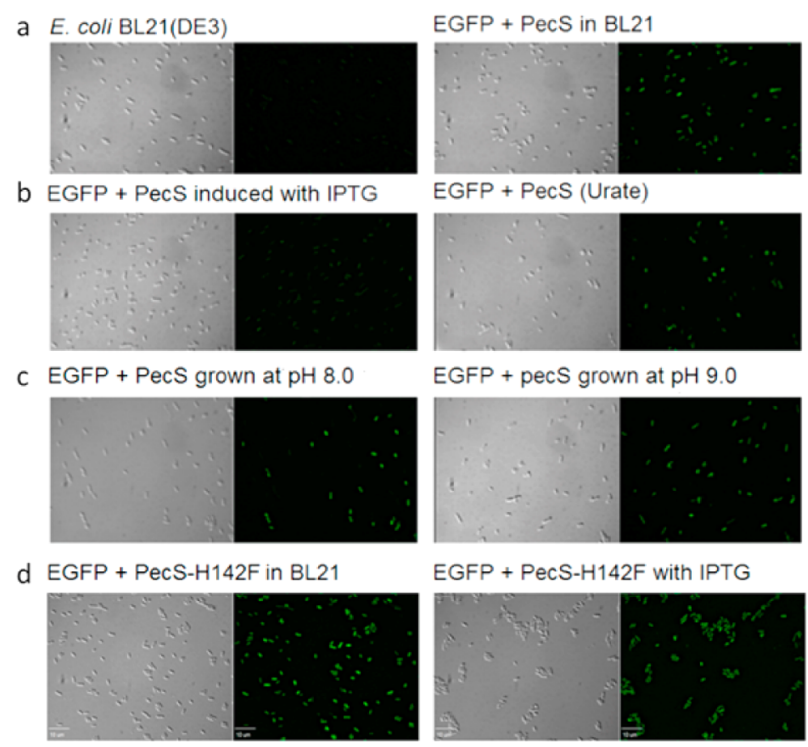

Figure 7. Alkaline $\mathrm{pH}$ relieves PecS-mediated repression of the pecS promoter in vivo. Phase contrast (left) and fluorescent micrographs (right) are shown. (a) E. coli harboring no plasmids (left column) and E. coli transformed with plasmids carrying genes encoding EGFP and PecS (no IPTG induction, right column). (b) E. coli transformed with plasmids carrying genes encoding EGFP and PecS induced with IPTG without (left) and with urate (right) at $\mathrm{pH}$ 7.4. (c) E. coli transformed with plasmids carrying genes encoding EGFP and PecS induced with IPTG at $\mathrm{pH} 8.0$ (left) or at $\mathrm{pH} 9.0$ (right). (d) E. coli transformed with plasmids carrying genes encoding EGFP and PecS-H142F without (left) or with IPTG induction of PecS-142F expression at $\mathrm{pH}$ 7.4. The scale bar represents $10 \mu \mathrm{m}$ and is same for all micrographs.

ligand for PecS in vivo and triggers derepression of the pecS promoter.

To determine if PecS control of the pecS promoter is $\mathrm{pH}$ dependent, the strain harboring pACYC184_EGFP_pecO and pET100-PecS was grown at $\mathrm{pH} 8.0$ and 9.0 and PecS expression was induced with IPTG (Supporting Information Figure S9). E. coli usually maintains its cytoplasmic $\mathrm{pH}$ within a specific range of 7.4-7.8, with $\Delta \mathrm{pH}$ between extracellular and intracellular $\mathrm{pH}$ of $\sim 0.2$ and 0.5 for cells grown at $\mathrm{pH} 8$ and 9, respectively. ${ }^{26}$ The presence of EGFP fluorescence suggests that PecS failed to repress the pecS promoter when intracellular $\mathrm{pH}$ reached $\sim 7.8$ (extracellular $\mathrm{pH} \sim 8$; Figure $7 \mathrm{c}$ ), as reflected in fluorescence in both uninduced (Supporting Information Figure S10) and IPTG-induced cultures. These data substantiate DNase I experiments, which show that DNA distortion by $\mathrm{PecS}$ is $\mathrm{pH}$-dependent, and they suggest that the difference in extent of DNA distortion correlates with activity of the pecS promoter in vivo.

To examine whether the H142F mutation impacts pecS promoter binding in vivo, the strain carrying pACYC184_EGFP_pecO and pET100-PecS-H142F was cultured with and without IPTG at $\mathrm{pH}$ 7.4. We observed EGFP fluorescence in both uninduced and induced cultures (Figure $7 \mathrm{~d}$ ). This indicates that His 142 is required for repression of the pecS promoter by PecS, and it is consistent with the observation that DNA binding by PecS-H142F does not involve significant DNA distortion. An in vivo experiment with pET100-PecSH100F was not performed, due to the low expression of PecS$\mathrm{H} 100 \mathrm{~F}$ in comparison to wild type PecS.

Urate Attenuates DNA Binding by PecS. DNA binding of UrtR family transcriptional regulators is usually attenuated in the presence of urate. ${ }^{14,20,27,28}$ Consistent with this prediction, urate functioned as a PecS ligand in vivo (Figure $7 \mathrm{~b}$ ). Further, DNA binding of PecS was significantly attenuated in the presence of urate with an $\mathrm{IC}_{50}$ of $7.6 \pm 0.1 \mathrm{mM}$ (Supporting Information Figure S11). Based on the $\mathrm{IC}_{50}$, an apparent inhibition constant $K_{\mathrm{i}}$ of $2.1 \mathrm{mM}$ was estimated (the $0.5 \mathrm{M}$ Tris included in the reaction buffer to prevent changes in $\mathrm{pH}$ on addition of urate dissolved in $0.4 \mathrm{M} \mathrm{NaOH}$ reduces the affinity of urate). Evidently, P. atrosepticum PecS likewise responds to urate by attenuated DNA binding.

To confirm direct ligand binding, we measured intrinsic tryptophan fluorescence of $\mathrm{PecS}$ as a function of urate concentration; the addition of increasing concentration of urate $(5-100 \mu \mathrm{M})$ resulted in gradual quenching of intrinsic fluorescence (Supporting Information Figure S12). We also performed a thermal shift assay to monitor the effect of urate on protein stability. The fluorescence intensity of SYPRO Orange fluorescent reporter was measured as a function of temperature. A one step melting transition was observed for unbound protein with a melting temperature of $50.0 \pm 0.4{ }^{\circ} \mathrm{C}$ (Supporting Information Figure S13 and Table S1). The addition of $10 \mu \mathrm{M}$ urate to PecS resulted in a decrease of the melting temperature of $\sim 4{ }^{\circ} \mathrm{C}$, whereas the addition of higher urate concentration $(100 \mu \mathrm{M})$ led to a further decrease in melting temperature $\left(T_{\mathrm{m}} \sim 45{ }^{\circ} \mathrm{C}\right)$. This suggests that conformational changes in PecS are induced at a micromolar concentration of urate. By comparison, the affinity of urate for A. fabrum PecS and D. radiodurans HucR is $\sim 10 \mu \mathrm{M}^{14,29}$

\section{DISCUSSION}

Physiological Relevance of pH Dependence. Phytopathogenic bacteria depend on sensing and responding to environmental cues for efficient colonization of host plants, often subverting host defenses by utilizing plant-derived signals to trigger upregulation of virulence genes. MarR family transcriptional regulators mediate such adaptive responses to different environmental stimuli. ${ }^{2,18} P$. atrosepticum $\mathrm{PecS}$ binds to the intergenic region of $p e c S-p e c M$ with high affinity and specificity (Figure 2), and it efficiently represses the pecS promoter in vivo at neutral $\mathrm{pH}$ (Figure 7 ). This would be consistent with the ability of PecS to prevent premature expression of virulence genes during early stages of colonization. PecS binds to two sites in the pecS-pecM intergenic region (Figure 4); given that only 62 bp separate the start codons of pecM and pecS, we infer that PecS binding to either site would repress transcription of both genes.

By comparison, DNase I footprinting of $D$. dadantii PecS on the corresponding pecS-pecM intergenic DNA revealed two protected regions of 32 and $45 \mathrm{bp}$, respectively, with each region characterized by a relatively high $\mathrm{A}+\mathrm{T}$-content, but no identifiable palindromes. ${ }^{13,30}$ For A. fabrum PecS, two protected regions were likewise seen, both corresponding to palindromes that resemble the UrtR consensus. ${ }^{14}$

Production of the main pectate lyases in $D$. dadantii is subject to complex regulation. On these genes, the affinity of PecS is $\sim 10$-fold lower than for the site in the pecS/pecM promoter, and it was not possible to footprint PecS alone. ${ }^{30,31}$ Similarly, it is conceivable that $P$. atrosepticum $\mathrm{PecS}$ recognizes more degenerate sequences in other gene promoters. For example, the promoters driving expression of the three major pectate lyases PelA, PelB, and PelC encoded by ECA_RS20105ECA_RS20115 all feature a highly conserved site with consensus sequence AAATTCTAT-TCCAAGGAG, in which 
each half-site conserves 3 and $5 \mathrm{bp}$, respectively, of the consensus PecS site in the pecS-pecM intergenic DNA.

PecS represses gene expression at neutral $\mathrm{pH}$. This observation supports previous reports that expression of virulence genes such as genes encoding pectate lyases is low at acidic $\mathrm{pH}$. During the initial phase of colonization, there is no production of plant cell-wall-degrading enzymes. ${ }^{32}$ Once bacteria colonize the plant intercellular spaces, the onset of pathogenesis begins with alkalization of the plant apoplast, ${ }^{10}$ which is necessary as pectate lyase functions above $\mathrm{pH}$ 8.0. Thus, we propose that the altered mode of DNA binding by $\mathrm{PecS}$ at alkaline $\mathrm{pH}$ contributes to a gradual onset of virulence gene expression and therefore pathogenesis of P. atrosepticum.

Modulation of Promoter DNA Topology. PecS binds DNA with comparable affinity regardless of $\mathrm{pH}$, yet repression of the pecS promoter is effectively abrogated at extracellular $\mathrm{pH}$ $\sim 8$ (where E. coli is expected to maintain its intracellular $\mathrm{pH} \sim$ $7.8 ;^{26}$ Figure 7). Notably, the binding of PecS to DNA introduces marked distortion at cognate sites at neutral $\mathrm{pH}$, as evidenced by the presence of significant hypersensitive sites (Figures 4 and 5). However, an increase in $\mathrm{pH}$ is associated with severe attenuation of hypersensitive cleavage, indicating that the DNA distortion induced by PecS in its repressive mode (at $\mathrm{pH} \sim 7$ ) is attenuated at $\mathrm{pH} \sim 8$, where DNA binding does not repress gene activity. The $38 \mathrm{bp}$ distance between the centers of identified palindromes would correspond to $\sim 3.5$ helical turns, which would place two PecS dimers on opposite faces of the duplex, assuming $B$-form DNA. This binding mode might apply at $\mathrm{pH} 8.3$ when little DNA distortion is induced on DNA binding (Figure 8). The significant distortion induced at

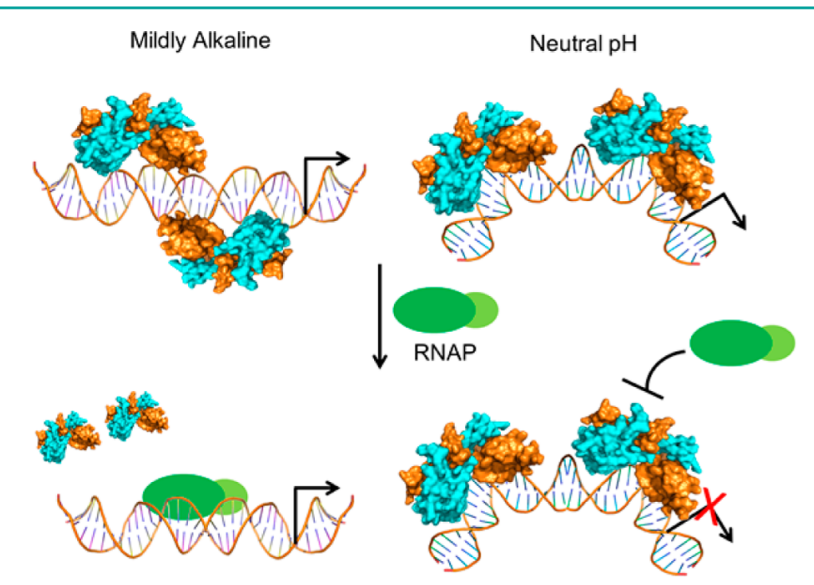

Figure 8. PecS-induced DNA conformational changes at neutral $\mathrm{pH}$ lead to repression of gene activity. At neutral $\mathrm{pH}$ (right), two PecS dimers bind the pecS-pecM intergenic region and cause a significant DNA distortion that is incompatible with RNA polymerase (RNAP; green) binding to the promoter. At mildly alkaline $\mathrm{pH}$ (left), little DNA distortion is induced on PecS binding, allowing RNA polymerase to displace promoter-bound PecS. RNAP not drawn to scale.

neutral $\mathrm{pH}$ may involve DNA bending or unwinding and may force a different position of PecS dimers relative to each other. We speculate that PecS may impose conformational changes in promoter DNA that adversely affect the ability of RNA polymerase to bind or initiate transcription, but only at neutral $\mathrm{pH}$ (Figure 8). At the permissive $\mathrm{pH}$ near 8, PecS binding does not lead to large conformational changes, and productive recruitment of RNA polymerase may occur.
That the change in DNA binding and regulatory activity is manifest on increasing $\mathrm{pH}$ from neutral to mildly alkaline prompted the consideration that histidine deprotonation might contribute to these observations. H100 in the DNA recognition helix appears to contribute only modestly; its substitution to Phe leads to an apparent decrease in DNA binding affinity and reduced specificity. However, hypersensitive cleavage sites are still present (Figure 6a), suggesting that PecS-H100F induces comparable distortions in the DNA as wild-type PecS. Since $\mathrm{H} 100$ is predicted to contact DNA, accessibility of this residue to modification by DEPC is likely to be reduced on DNA binding (Figure $3 \mathrm{~b}$ ).

H142 in $\alpha 6$ is located in a crevice between the dimerization and DNA-binding regions (Figure $1 \mathrm{~b}$ ). Mutation of H142 did not appear to affect affinity or specificity; however, hypersensitive sites were much less pronounced on PecS-H142F binding and similar to the patterns induced by wild-type PecS at $\mathrm{pH} 8.3$ (Figure 5). Consistent with this observation, PecS$\mathrm{H} 142 \mathrm{~F}$ was unable to repress the pecS promoter in vivo (Figure $7 \mathrm{~d}) . \mathrm{H} 142$ is predicted to occupy the same position in PecS as it does in the structure of HucR; ${ }^{23}$ however, in the PecS model, a glutamate (E146) is predicted to be near $\mathrm{H} 142$, in a position to stabilize a positive charge on $\mathrm{H} 142$. Such a charge stabilization would be predicted to increase the $\mathrm{p} K_{\mathrm{a}}$ of $\mathrm{H} 142$, perhaps ensuring that changes in DNA binding are manifest on increasing the $\mathrm{pH}$ from neutral to mildly alkaline (and explaining the absence of a similar $\mathrm{pH}$-sensitivity in HucR). We therefore propose that protonation of His142 at neutral $\mathrm{pH}$ is associated with a PecS conformation in which DNA distortion is required to accommodate DNA recognition helices. On deprotonation of PecS (or the H142F substitution), such DNA distortion is no longer required for binding.

Gene Regulation by Urate. The host plant responds to bacterial infection by production of reactive oxygen species (ROS). Peroxisomes are a major site of intracellular ROS production, and one of the enzymes responsible is xanthine oxidase. $^{15,16}$ Xanthine oxidase, which is also found in the cytoplasm, converts hypoxanthine to xanthine and xanthine to urate in the process of generating ROS. While numerous studies have implicated ROS production by xanthine oxidase in stress responses, and the ability of urate to induce arrest of pathogen growth, ${ }^{33}$ concentrations of the products xanthine and urate, which would be expected to accumulate transiently and locally in response to infection, have not been estimated under pathological conditions in plants. Urate attenuates the binding of $P$. atrosepticum PecS to the pecS-pecM intergenic region in vitro and in vivo, consistent with the inference that it may act as a signaling molecule for the bacterium. Taken together, we propose that derepression of genes under PecS control may be achieved by two mechanisms, a $\mathrm{pH}$ independent association of $\mathrm{PecS}$ with urate that results in protein dissociation from cognate DNA and a $\mathrm{pH}$-dependent deprotonation of $\mathrm{H} 142$ at mildly alkaline $\mathrm{pH}$ that abrogates the PecS-induced conformational changes in promoter DNA that interfere with RNA polymerase recruitment.

\section{METHODS}

Protein Modeling and Preparation. The PecS model was generated by homology modeling using the structure of HucR (PDB ID: 2 FBK; $31 \%$ sequence identity) as a template. ${ }^{23}$

The gene encoding $P$. atrosepticum SCRI 1043 PecS (ECA_RS10035) was expressed with an $\mathrm{N}$-terminal $\mathrm{His}_{6}$-tag. Sitedirected mutagenesis of PecS was performed by whole plasmid PCR 
using the recombinant plasmid containing the PecS gene as a template. Protein was expressed in E. coli and purified by metal-affinity chromatography.

DNA Binding Assays. For electrophoretic mobility shift assays, the 92-bp ( pecO) DNA comprising the pecS-pecM intergenic region was labeled with ${ }^{32} \mathrm{P}$. An increasing concentration of $\mathrm{PecS}$ was incubated with $0.1 \mathrm{nM}{ }^{32}$ P-labeled pecO in a binding buffer $(50 \mathrm{mM}$ Tris (pH 7.4), $200 \mathrm{mM} \mathrm{NaCl}, 0.05 \%$ Brij58, $20 \mu \mathrm{g} \mathrm{mL}^{-1} \mathrm{BSA}$, and $4 \%$ glycerol). Complex and free DNA were separated by electrophoresis followed by phosphorimaging. Data were fit to the Hill equation $f=$ $f_{\max }[\mathrm{P}]^{n_{\mathrm{H}}} /\left(K_{\mathrm{d}}+[\mathrm{P}]^{n_{\mathrm{H}}}\right)$, where $K_{\mathrm{d}}$ is the apparent equilibrium dissociation constant, $n_{\mathrm{H}}$ is Hill coefficient, $f_{\max }$ is the maximal fractional saturation, and $[\mathrm{P}]$ is the protein concentration. Data from filter binding assays were processed as described above to determine apparent $K_{\mathrm{d}}$.

DNase I footprinting was performed by fragment analysis. ${ }^{25}$ A 317 bp 6-carboxyfluorescein-labeled DNA probe containing the pecS-pecM intergenic region was used. Binding reactions consisting of $30 \mathrm{ng}$ (14 $\mathrm{nM}$ ) of fluorescently labeled DNA were incubated with and without protein in binding buffer ( $50 \mathrm{mM}$ Tris ( $\mathrm{pH} 7.4$ or 8.0$), 200 \mathrm{mM} \mathrm{NaCl}$, $0.05 \%$ Brij58, $20 \mu \mathrm{g} \mathrm{mL}^{-1} \mathrm{BSA}$, and $4 \%$ glycerol), followed by addition of $1 \mu \mathrm{L}$ of $10 \times$ DNase I reaction buffer and $0.05 \mathrm{U}$ of DNase I.

Fluorescence Microscopy. The gene encoding d1EGFP under control of the pecS promoter ( $p e c O)$ was cloned into pACYC184. The pACYC184 EGFP pecO construct and expression vector pET100/ D-TOPO (harboring the pecS or the pecS-H142F gene) were cotransformed into E. coli Bl21(DE3). The cells were grown at $37{ }^{\circ} \mathrm{C}$ to an $\mathrm{OD}_{600}$ of $0.5-0.6$ with or without IPTG $(0.3 \mathrm{mM})$. Cells were harvested and observed using DIC (differential interference contrast) and fluorescence microscopy. Where required, urate was added to a final concentration of $10 \mathrm{mM}$. For analysis of the effect of $\mathrm{pH}$ on gene expression, cells were grown at $\mathrm{pH} 8.0$ and $\mathrm{pH} 9.0$.

Additional experimental details for all procedures are available in the Supporting Information.

\section{ASSOCIATED CONTENT}

\section{S Supporting Information}

The Supporting Information is available free of charge on the ACS Publications website at DOI: 10.1021/acschembio.6b00168.

Figures showing sequence alignment of MarR proteins; conservation of pecS-pecM gene pairs; SDS-PAGE gel, gel filtration, and CD spectrum of PecS; DNA binding isotherm; EMSA of complex formation at $\mathrm{pH}$ 8.3; filterbinding assay; DNase I footprint of PecS and mutant proteins at different ratios of DNA/protein; EMSA of PecS-H100F; SDS-PAGE gel showing expression of PecS at different $\mathrm{pH}$; expression of EGFP at $\mathrm{pH} 8.0$ and 9.0; attenuation of DNA binding by urate; tryptophan fluorescence spectra of PecS without and with urate; and thermal stability of PecS without and with urate and also supplemental methods (PDF)

\section{AUTHOR INFORMATION}

\section{Corresponding Author}

*E-mail: agrove@lsu.edu.

\section{Author Contributions}

The manuscript was written through contributions of all authors. All authors have given approval to the final version of the manuscript.

\section{Funding}

Supported by the National Science Foundation (MCB-1051610 and MCB-1515349 to A.G.).

\section{Notes}

The authors declare no competing financial interest.

\section{ACKNOWLEDGMENTS}

We thank H. Hale-Donze from the Socolofsky Microscopy Center for assistance with fluorescence microscopy, T. Gauthier for help with CD spectroscopy, and M. Newcomer for the use of FPLC, spectrofluorometer, and spectrophotometer.

\section{ABBREVIATIONS}

DEPC, diethylpyrocarbonate; EGFP, enhanced green fluorescent protein; EMSA, electrophoretic mobility shift assay; IPTG, isopropyl- $\beta$-D-1-thiogalactopyranoside; MarR, multiple antibiotic resistance regulator; PMSF, phenylmethylsulfonyl fluoride; ROS, reactive oxygen species; UrtR, urate responsive transcriptional regulator

\section{REFERENCES}

(1) deHaseth, P. L., Zupancic, M. L., and Record, M. T., Jr. (1998) RNA polymerase-promoter interactions: the comings and goings of RNA polymerase. J. Bacteriol. 180, 3019-3025.

(2) Ellison, D. W., and Miller, V. L. (2006) Regulation of virulence by members of the MarR/SlyA family. Curr. Opin. Microbiol. 9, 153-159.

(3) Grove, A. (2013) MarR family transcription factors. Curr. Biol. 23, R142-143.

(4) Perera, I. C., and Grove, A. (2010) Molecular mechanisms of ligand-mediated attenuation of DNA binding by MarR family transcriptional regulators. J. Mol. Cell Biol. 2, 243-254.

(5) Wilkinson, S. P., and Grove, A. (2006) Ligand-responsive transcriptional regulation by members of the MarR family of winged helix proteins. Curr. Issues Mol. Biol. 8, 51-62.

(6) Czajkowski, R., Perombelon, M. C. M., Jafra, S., Lojkowska, E., Potrykus, M., van der Wolf, J. M., and Sledz, W. (2015) Detection, identification and differentiation of Pectobacterium and Dickeya species causing potato blackleg and tuber soft rot: a review. Ann. Appl. Biol. 166, 18-38.

(7) Cubitt, M. F., Hedley, P. E., Williamson, N. R., Morris, J. A., Campbell, E., Toth, I. K., and Salmond, G. P. (2013) A metabolic regulator modulates virulence and quorum sensing signal production in Pectobacterium atrosepticum. Mol. Plant-Microbe Interact. 26, 356366.

(8) Pérez-Mendoza, D., Coulthurst, S. J., Sanjuán, J., and Salmond, G. P. C. (2011) N-Acetylglucosamine-dependent biofilm formation in Pectobacterium atrosepticum is cryptic and activated by elevated c-diGMP levels. Microbiology 157, 3340-3348.

(9) Hugouvieux-Cotte-Pattat, N., Condemine, G., and Shevchik, V. E. (2014) Bacterial pectate lyases, structural and functional diversity. Environ. Microbiol. Rep. 6, 427-440.

(10) Marquez-Villavicencio, M. d. P., Weber, B., Witherell, R. A., Willis, D. K., and Charkowski, A. O. (2011) The 3-Hydroxy-2Butanone Pathway Is Required for Pectobacterium carotovorum Pathogenesis. PLoS One 6, e22974.

(11) Sutherland, M. W. (1991) The generation of oxygen radicals during host plant responses to infection. Physiol. Mol. Plant Pathol. 39, 79-93.

(12) Hommais, F., Oger-Desfeux, C., Van Gijsegem, F., Castang, S., Ligori, S., Expert, D., Nasser, W., and Reverchon, S. (2008) PecS Is a Global Regulator of the Symptomatic Phase in the Phytopathogenic Bacterium Erwinia chrysanthemi 3937. J. Bacteriol. 190, 7508-7522.

(13) Praillet, T., Reverchon, S., and Nasser, W. (1997) Mutual control of the PecS/PecM couple, two proteins regulating virulencefactor synthesis in Erwinia chrysanthemi. Mol. Microbiol. 24, 803-814.

(14) Perera, I. C., and Grove, A. (2010) Urate is a ligand for the transcriptional regulator PecS. J. Mol. Biol. 402, 539-551.

(15) del Rio, L. A., Corpas, F. J., Sandalio, L. M., Palma, J. M., and Barroso, J. B. (2003) Plant peroxisomes, reactive oxygen metabolism and nitric oxide. IUBMB Life 55, 71-81.

(16) Corpas, F. J., Palma, J. M., Sandalio, L. M., Valderrama, R., Barroso, J. B., and Del Rio, L. A. (2008) Peroxisomal xanthine 
oxidoreductase: characterization of the enzyme from pea (Pisum sativum L.) leaves. J. Plant Physiol. 165, 1319-1330.

(17) Perera, I. C., and Grove, A. (2011) MarR homologs with uratebinding signature. Protein Sci. 20, 621-629.

(18) Perera, I. C., Lee, Y. H., Wilkinson, S. P., and Grove, A. (2009) Mechanism for attenuation of DNA binding by MarR family transcriptional regulators by small molecule ligands. J. Mol. Biol. 390, $1019-1029$.

(19) Franceschini, A., Szklarczyk, D., Frankild, S., Kuhn, M., Simonovic, M., Roth, A., Lin, J., Minguez, P., Bork, P., von Mering, C., and Jensen, L. J. (2013) STRING v9.1: protein-protein interaction networks, with increased coverage and integration. Nucleic Acids Res. 41, D808-815.

(20) Huang, H., Mackel, B. J., and Grove, A. (2013) Streptomyces coelicolor encodes a urate-responsive transcriptional regulator with homology to PecS from plant pathogens. J. Bacteriol. 195, 4954-4965. (21) Rouanet, C., and Nasser, W. (2001) The PecM protein of the phytopathogenic bacterium Erwinia chrysanthemi, membrane topology and possible involvement in the efflux of the blue pigment indigoidine. J. Mol. Microbiol Biotechnol 3, 309-318.

(22) Reverchon, S., Rouanet, C., Expert, D., and Nasser, W. (2002) Characterization of indigoidine biosynthetic genes in Erwinia chrysanthemi and role of this blue pigment in pathogenicity. $J$. Bacteriol. 184, 654-665.

(23) Bordelon, T., Wilkinson, S. P., Grove, A., and Newcomer, M. E. (2006) The crystal structure of the transcriptional regulator HucR from Deinococcus radiodurans reveals a repressor preconfigured for DNA binding. J. Mol. Biol. 360, 168-177.

(24) Hondal, R. J., Ma, S., Caprioli, R. M., Hill, K. E., and Burk, R. F. (2001) Heparin-binding histidine and lysine residues of rat selenoprotein P. J. Biol. Chem. 276, 15823-15831.

(25) Sivapragasam, S., Pande, A., and Grove, A. (2015) A recommended workflow for DNase I footprinting using a capillary electrophoresis genetic analyzer. Anal. Biochem. 481, 1-3.

(26) Padan, E., Zilberstein, D., and Rottenberg, H. (1976) The proton electrochemical gradient in Escherichia coli cells. Eur. J. Biochem. 63, 533-541.

(27) Gupta, A., and Grove, A. (2014) Ligand-binding pocket bridges DNA-binding and dimerization domains of the urate-responsive MarR homologue MftR from Burkholderia thailandensis. Biochemistry 53, 4368-4380.

(28) Wilkinson, S. P., and Grove, A. (2004) HucR, a novel uric acidresponsive member of the MarR family of transcriptional regulators from Deinococcus radiodurans. J. Biol. Chem. 279, 51442-51450.

(29) Wilkinson, S. P., and Grove, A. (2005) Negative cooperativity of uric acid binding to the transcriptional regulator $\mathrm{HucR}$ from Deinococcus radiodurans. J. Mol. Biol. 350, 617-630.

(30) Praillet, T., Nasser, W., Robert-Baudouy, J., and Reverchon, S. (1996) Purification and functional characterization of PecS, a regulator of virulence-factor synthesis in Erwinia chrysanthemi. Mol. Microbiol. 20, 391-402.

(31) Rouanet, C., Nomura, K., Tsuyumu, S., and Nasser, W. (1999) Regulation of pelD and pelE, encoding major alkaline pectate lyases in Erwinia chrysanthemi: involvement of the main transcriptional factors. J. Bacteriol. 181, 5948-5957.

(32) Lebeau, A., Reverchon, S., Gaubert, S., Kraepiel, Y., SimondCôte, E., Nasser, W., and Van Gijsegem, F. (2008) The GacA global regulator is required for the appropriate expression of Erwinia chrysanthemi 3937 pathogenicity genes during plant infection. Environ. Microbiol. 10, 545-559.

(33) Alamillo, J. M., and Garcia-Olmedo, F. (2001) Effects of urate, a natural inhibitor of peroxynitrite-mediated toxicity, in the response of Arabidopsis thaliana to the bacterial pathogen Pseudomonas syringae. Plant J. 25, 529-540. 